\title{
Nogle grundbegreber i Grundtvigs pædagogiske tanker
}

\section{Af K. E. Bugge med bilag ved Bjørn Krab-Johansen}

I den følgende redegørelse rettes søgelyset først mod det metodiske spørgsmål: Hvorledes kan man definere og studere "nogle grundbegreber i Grundtvigs pædagogiske tanker"? Dernæst fokuseres på to grundbegreber, liv og lys, deres indhold og forhold til hinanden. Afsluttende gøres opmærksom på de negative og 'usynlige' grundbegreber. De sidstnævnte er de grundbegreber, der ikke udtrykkeligt nævnes i teksten, men som man bl.a. på grundlag af udkastene kan se har været til stede i Grundtvigs overvejelser.

\section{Definitioner}

Et grundbegreb vil de fleste nok definere som et begreb, der er hyppigt forekommende i en bestemt kontekst. Begreberne demokrati og diktatur forekommer hyppigt $\mathrm{i}$ den politiske debat og må derfor opfattes som politiske grundbegreber. Ud fra en tilsvarende iagttagelse vil man kunne betegne synd og nåde som grundbegreber inden for luthersk teologi. Og som eksempler på pædagogiske grundbegreber nævner K. Grue-Sørensen (1974) bl.a. begreberne adfærd, dannelse, forståelse og motivation. Ingen vil nægte, at disse er hyppigt forekommende i den pædagogiske debat.

Et grundbegreb kan imidlertid også forstås som et begreb, der er grundloggende. Det vil med andre ord sige, at det er basalt eller fundamentalt derved, at det ligger til grund for et eller flere andre begreber. En sådan opfattelse vil være smukt i overensstemmelse med de definitioner, der foreligger på engelsk, tysk og fransk. ${ }^{1}$

\section{Tilgange}

Til studiet af grundbegreberne i Grundtvigs pædagogiske tænkning er det nærliggende at vælge en af to tilgange:

Går man ud fra den først nævnte definition af et grundbegreb, ifølge hvilken begrebets forekomst $i$ en eller flere tekster er det interessante, er tilgangen forholdsvis enkel. Eksempler på nogle af de begreber, der hyppigt forekommer i Grundtvigs pædagogiske tekster, er - anført i vilkårlig rækkefølge: liv - frihed - naturlighed - lys oplysning - mundtlighed - folkelig og historisk-poetisk. Relevante tekster er tilgængelige på internettet. Hvor hyppigt begreberne forekommer, kan derfor let fastslås ved hjælp af en computer. ${ }^{2}$ At 
begrunde de konstaterede variationer $\mathrm{i}$ forekomsten er straks mere krævende.

Går man ud fra den anden definition, ifølge hvilken et grundbegreb er et begreb, der ligger til grund for et eller flere andre begreber, bliver opgaven mangefold sværere. Er denne definition udgangspunktet, da kan man nemlig ikke nøjes med blot at konstatere en rent sproglig sammenhæng som fx mellem begreberne lys - oplysning - folkeoplysning - livsoplysning. Langt sværere, men også langt mere interessant bliver det, dersom man kan påvise en indholdsmaessig sammenhæng mellem et grundbegreb og en række andre begreber, som det ikke har nogen sproglige lighedspunkter med, men som alligevel i Grundtvigs tankeverden er nært forbundne med hinanden. Et nærliggende eksempel er: liv $\rightarrow$ levende ord $\rightarrow$ mundtlighed $\rightarrow$ modersmål $\rightarrow$ danskhed $\rightarrow$ folkelighed - og langt ude i horisonten: menneskelivets forklaring.

Allerede af disse eksempler fremgår, at der med hensyn til studiet af grundbegrebernes forhold til de begreber, de ligger til grund for, foreligger et væld af muligheder for varierende opfattelser og fortolkninger. Vigtigt er under alle omstændigheder spørgsmålet om prioritering, med andre ord: Spørgsmålet, om der ikke er nogle grundbegreber, der er mere basale end andre? For at komme et skridt videre kunne jeg tænke mig, at man sondrede mellem primare og sekundcere grundbegreber. Ved primære grundbegreber forstås i så fald begreber, der ikke har andre begreber som grundlag eller udgangspunkt. Eksempler på sådanne primære grundbegreber er liv og lys. Ved sekundære grundbegreber forstås derimod begreber, der forholder sig i et nærmere eller fjernere forhold - enten sprogligt eller indholdsmæssigt - til et andet, mere grundlæggende, begreb, jf. ovenfor.

Endelig kunne der være grund til at overveje de primære grundbegrebers forhold til hinanden. Det kommer vi tilbage til.

\section{To primære grundbegreber}

Hvad angår grundbegrebernes indhold, er valget er faldet på de to primære grundbegreber liv og lys. Om det første forholder det sig så heldigt, at der kan henvises til en trykt redegørelse. ${ }^{3}$ Vi kan derfor her samle opmærksomheden om lyset - uden at livet dog derved helt forsømmes.

Det sekundære grundbegreb oplysning optræder i Grundtvigs forfatterskab lige fra 1804 (US I, 36) og helt frem til 1850'erne og 1860 'erne. De første udførlige refleksioner vedrørende det i forhold dertil primære grundbegreb lys hidrører imidlertid fra årene efter 1810. Et centralt dokument i så henseende er Grundtvigs landemodetale fra 
juli 1812, Om Oplysning $i$ Almindelighed og om Almueoplysning $i$ Scerdeleshed. En hovedtanke i denne tidlige tekst er, at sand oplysning henter sit lys fra Gud, fra "Lysenes Fader". Den falske oplysning, derimod, har sit udspring hos Satan, der "omskaber sig til en Lysets Engel". Den sande oplysnings indhold er "Undervisning om vore Vilkaar, om hvad vi skal tro og gøre for at vorde delagtige i det visse evige Liv". ${ }^{4}$ Lys-begrebet, som her er ensidigt teologisk funderet, kan med Ove Korsgaards udtryk betegnes som "Lyset oppefra" (Korsgaard 1999). I kirkelig/teologisk sammenhæng fastholdes dette grundsyn gennem hele forfatterskabet. Karakteristisk i så henseende er det sene digt Oplysningen fra 1862-63, hvor det bl.a. hedder:

Uden Lys tal aldrig om

Sandheds Tro og Christendom

(...) //

Kom ihu, at Herrens Ord

Er det Lys, som kom til Jord

Og skal Verden dømme. (GSV V, 475-476)

I pædagogiske tekster, derimod, er lys-begrebet fra og med 1830'erne funderet $\mathrm{i}$ en menneskelig sammenhæng. Kun indirekte kommer lyset ovenfra. Dets udspring er at finde i en "horisontal" kontekst, i menneskelivet som det udfolder sig i historisk og folkelig sammenhæng. $\mathrm{Nu}$ er det Grundtvig om at gøre at præcisere, at oplysningen udspringer af menneskelivet, at dets formål er at tjene det praktiske hverdagsliv og i et videre perspektiv at bidrage til "Menneskelivets Forklaring". Nu hedder det, at fordi livet hos os mennesker altid går foran lyset, derfor må man "lade sig lære og lede af Menneske-Naturen og MenneskeErfaringen" (Lykønskning til Danmark 1847, GSkV II, 254).

Også denne tankegang kan følges op gennem hele forfatterskabet indtil Grundtvigs død. Som illustrationer kan nævnes de tre digte, der indgår i Smaaskrifter, og som i 1872 udvalgtes i et samarbejde mellem Grundtvig og højskoleforstander Carl Grove. Det drejer sig om (a) "Er Lyset for de Lærde blot" (1839), (b) "Danmark, gamle SkjoldungRige" (1848), og (c) Solsangen: "Hvad Soelskin er for det sorte Muld" (1856).

I det første digt (1839) hedder det, at Vorherre vidner, dvs. bevidner, at lys er godt, ${ }^{5}$ og at lys er "Himlens Gave"; i samme åndedrag fastslås, at "Solen staaer med Bonden op". Det er altså i den nære arbejdssammenhæng, at man møder det lys, man har brug for. - (b) I det andet af digtene (1848) hedder det, at i den nye skole skal "Lyset, som dertil er givet, / Kaste Glands paa Livet". - (c) I solsangen (1856) understreges, at "sand Oplysning" (NB: udtrykket anvendes to gange!) er "Livs-Oplysning", "Det er sin Gud og sig selv at kiende". Det er med andre ord menneskelivets forklaring i videst mulige perspektiv. 
En dertil svarende forståelse af disse linjer foreligger i Regnar Birkelunds bidrag til særhæftet om Livsoplysning $(1999,26)$.

Hermed er vi fremme ved forholdet mellem de to primære grundbegreber lys og liv. Netop disse to begreber bliver i Grundtvigs pædagogiske tænkning ofte knyttet nært sammen: "Lyset og Livet er Tvillinger bolde, / Døden alene kan skille dem ad!" Disse to linjer har Grundtvig anført som mottovers for Skolen for Livet og Academiet $i$ Soer (1838). At lys og liv kaldes tvillinger, må betyde, dels at de er "lige gamle" og derfor lige værdige, dels at de har et meget nært forhold til hinanden. Med rette har Helge Toldberg fastslået, at lys og liv "i grunden er ét" (Toldberg 1950, 119). De er ikke modsætninger, og det ville derfor være misvisende at betegne deres indbyrdes forhold som dialektisk. Det er ikke gennem smertelige kriser, men gennem venlig kappestrid, at de driver en udvikling fremad, dvs. en kappestrid,

Om Liv at udvikle, som Lyset er værd,

Om Lys at udbrede for Livet især. (PS VI, 565)

\section{Negative og usynlige grundbegreber}

Under studiet af Grundtvigs pædagogiske grundbegreber er det vigtigt, at man ikke glemmer de negative begreber, hvormed han betegner alt det uvæsen, han ønsker at bekæmpe i skolens verden. Et udgangspunkt for et sådant studium kunne være en gennemgang af den her i indledningsafsnittet til Noter nævnte emneliste i Borups og Schrøders Haandbog fra 1929. Den anfører fx Abekatteri, Boglærdom, Den sorte Skole, Drengevidenskabelighed, Døde Sprog, Examen, kritiskhistorisk Hakkemad, Latineri, Ramseri, Skolegraven (også Skolen for Døden), Skoletvang, Stilebaand, Udenadslæsning. Der er nok at tage fat på. I skriftet om Statsmaessig Oplysning fra 1834 finder man endvidere, at en hovedintention bag Grundtvigs skoletanker er at bekæmpe det, han kalder "Enkeltmandens Egenraadighed", dvs. individets fællesskabsdræbende selvhævdelse.

Med henblik på at gennemføre en fuldt ud dækkende videnskabelig undersøgelse af Grundtvigs pædagogiske grundbegreber, er det endelig også nødvendigt at inddrage det omfattende utrykte forfatterskab. Gør man det, vil man opdage nogle "usynlige grund-begreber", dvs. grundbegreber, der er udeladt i den endelige tekst, men som forekommer i utrykte udkast til den pågældende passage.

Et tidligere benyttet eksempel (Bugge 1965, 322) vedrører grundbegrebet Vexel-Virkning. I en tekst fra 1843 hedder det i udkastet (Fasc. 355.1.a): "Hvorledes nu Vexel-Virkningen mellem Lærerne eller Lederne og Ungdommen kunde bedst finde Sted, det er vist nok et vigtigt Spørgsmaal." I den endelige, trykte tekst er "Vexel-Virknin- 
gen" mellem lærerne og ungdommen erstattet af andre begreber: "Hvorledes nu Ungdommens Ledere bedst skulde bære sig ad med at opelske og udbrede folkelig Dannelse og Oplysning, er vist nok et meget vigtigt Spørgsmaal" (GSkV II, 206). Her ses, at grundbegrebet "Vexel-Virkning" er usynligt til stede. Selv om det ikke findes i den endelige tekst, viser udkastet, at det er netop er det, Grundtvig har i tankerne.

Hermed er fremlagt nogle synspunkter til overvejelse og drøftelse.

\section{Forkortelser}

Fasc.: Fascikel, dvs. håndskriftskapsel i N. F. S. Grundtvigs arkiv på Det Kongelige Bibliotek, København.

GSkV: K. E. Bugge (udg.) (1968), Grundtvigs Skoleverden i tekster og udkast, I-II, København.

GSV I-VI: Th. Balslev et al. (1944-64), Grundtvigs Sang-Vark Samlet Udgave, bind 1-6, København.

HGS: Ernst J. Borup og Fr. Schrøder (udg.) (1929-31), Haandbog $i$ Grundtvigs Skrifter, I-III, København.

PS I-IX: Svend Grundtvig et al. (udg.) (1880-1930), N. F. S. Grundtvigs Poetiske Skrifter, bind 1-9, København.

US I-X: Holger Begtrup (udg.) (1904-09), Nik. Fred. Sev. Grundtvigs Udvalgte Skrifter, bind 1-10, København

\section{Litteraturliste}

\section{Voerker af N. F. S. Grundtvig}

Balslev, Th. et al. (1944-64), Grundtvigs Sang-Vork Samlet Udgave, bind 16 , København.

Begtrup. Holger (udg.) (1904-09), Nik. Fred. Sev. Grundtvigs Udvalgte Skrifter, bind 1-10, København

Borup, Ernst J. og Fr. Schrøder (udg.) (1929-31), Haandbog i Grundtvigs Skrifter, I-III, København.

Bugge, K. E. (udg.) (1968), Grundtvigs Skoleverden i tekster og udkast, I-II, København.

Grundtvig, Svend et al. (udg.) (1880-1930), N. F. S. Grundtvigs Poetiske Skrifter, bind 1-9, København.

\section{Voerker af andre forfattere}

Birkelund, Regner (1999), "Det grundtvigske og det rationalistiske oplysningsbegreb", KVAN Nr. 55, Temahæfte Livsoplysning, 17-29.

Bugge, K. E. (1965), Skolen for Livet. Studier over N. F. S. Grundtvigs poedagogiske tanker, København. 
Grue-Sørensen, K. (1974), Almen predagogik. En håndbog i de predagogiske grundbegreber, København.

Korsgaard, Ove (1999), "Hvor kommer lyset fra? Et idéhistorisk strejftog i oplysningens historie", KVAN Nr. 55, Temahæfte Livsoplysning, 31-44.

Toldberg, Helge (1950), Grundtvigs symbolverden, København.

\section{Noter}

Ovenstående redegørelse blev fremlagt 10. marts 2007 på et seminar om Grundtvig og skolen. Seminaret, der var organiseret af Udredningsudvalget vedrørende en ny videnskabelig udgave af Grundtvigs trykte skrifter, afholdtes på Den frie Lærerskole i Ollerup. Tidsrammen for hvert oplæg var en halv time.

Tekstgrundlaget er i overvejende grad Grundtvigs pædagogiske forfatterskab fra 1836 og fremefter, med andre ord de skrifter, som - med undtagelse af Bøn og Begreb fra 1840 - blev optrykt i Smaaskrifter om den historiske Høiskole, der blev udgivet i august 1872. En oversigt over de vigtigste af de begreber, man møder i disse tekster, foreligger i den "Emneliste", der afslutter første bind af Borup \& Schrøders Haandbog i N. F. S. Grundtvigs Skrifter fra 1929.

1 Oversættelser af "et grundbegreb":

Engelsk: A basic eller a fundamental concept.

Tysk: Ein Grundbegriff, idet "Grund" i denne forbindelse betyder grundvold eller fundament.

Fransk: Mens une notion er oversættelsen af "et begreb", betegner flertalsformen, les notions, "les premiers éléments d'une science", en videnskabs allerførste elementer, som de øvrige må bygge videre på.

2 Skrifterne er tilgængelige, dersom man via internettet besøger "Grundtvig-byen" (www.grundtvig-byen.dk). Ved at bruge grundbegreberne som søgeord kan man konstatere, hvor mange gange ordene forekommer i teksterne. Eksempelvis har Bjørn Krab-Johansen venligst undersøgt forekomsten af udvalgte primære og sekundære grundbegreber i Til Nordmaend om en Norsk Høi-Skole (1837) og i Skolen for Livet og Academiet $i$ Soer (1838), se bilag.

$3 \quad$ K. E. Bugge, "Grundtvigs syn på folkelig dannelse, dets muligheder før og nu." Trykt i Lilian Zøllner (red.), Almen dannelse, folkelig dannelse, folkelig livsoplysning (1993); genoptrykt i K. E. Bugge, Spor $i$ sne (1999). - Se endvidere H. Høirup, Fra døden til livet. Grundtvigs tanker om liv og død (1954, 2. udgave 1983).

4 Citeret fra Grundtvig-Studier 1958, 52 ff. - Tilsvarende tanker findes i afskedsdigtet til eleverne i Det Schouboeske Institut (PS I, 319-322). Se endvidere den udførlige tekst En Samtale, fra 1816-17, første gang trykt i Dansk Kirketidende 1886.

5 Det vil sige, at Vorherre bekræfter den almenmenneskelige erfaring: At "Lyset er godt", som det hedder i et dansk ordsprog, jf. Grundtvigs Danske Ordsprog og Mundheld (1845) nr. 1685. 


\section{Bilag}

ved Bjørn Krab-Johansen

\section{Forekomsten af nogle primære og sekundære pædagogiske grundbegreber i to af Grundtvigs skoleskrifter}

Skolen for Livet og Academiet i Soer (1838, 75 s., $\left.8^{\circ}\right)$

\begin{tabular}{|c|c|c|c|c|c|c|c|}
\hline \multicolumn{2}{|l|}{$\begin{array}{l}\text { Det primære } \\
\text { begreb "Liv" }\end{array}$} & \multicolumn{2}{|c|}{$\begin{array}{l}\text { Det primære } \\
\text { begreb "Lys" }\end{array}$} & \multicolumn{2}{|c|}{$\begin{array}{l}\text { Det sekundære } \\
\text { begreb "Modersmaal" }\end{array}$} & \multicolumn{2}{|c|}{$\begin{array}{l}\text { Det sekundære } \\
\text { begreb "Folkelighed" }\end{array}$} \\
\hline Borger-Liv & 3 & $\begin{array}{l}\text { Almeen- } \\
\text { Oplysning }\end{array}$ & 2 & Modersmaal & 21 & Folkelighed & 1 \\
\hline Borger-Livet & 2 & $\begin{array}{l}\text { Livs- } \\
\text { Oplysningen }\end{array}$ & 1 & & & & \\
\hline & & Lys & 1 & Modersmaalet & 37 & & \\
\hline Folkeliv & 1 & Lyse & 2 & Modersmaalets & 10 & & \\
\hline & & Lysere & 1 & & & & \\
\hline Folkelivet & 3 & Lyset & 4 & & & & \\
\hline Folke-Livet & 5 & Lysparti & 1 & & & & \\
\hline Liv & 43 & $\begin{array}{l}\text { Lys- } \\
\text { Udvikling }\end{array}$ & 1 & & & & \\
\hline Live & 1 & & & & & & \\
\hline Livet & 31 & Oplyse & 4 & & & & \\
\hline Livets & 7 & & & & & & \\
\hline Livlighed & 1 & Oplyses & 1 & & & & \\
\hline Livs & 1 & Oplysning & 19 & & & & \\
\hline Livsalige & 1 & Oplysningen & 3 & & & & \\
\hline Livsens & 1 & Oplysninger & 2 & & & & \\
\hline Livs-Kilde & 2 & $\begin{array}{l}\text { Oplysnings- } \\
\text { Anstalt }\end{array}$ & 1 & & & & \\
\hline Livskraft & 3 & $\begin{array}{l}\text { Oplysnings- } \\
\text { Sagen }\end{array}$ & 1 & & & & \\
\hline Livs-Kraften & 1 & Oplyst & 1 & & & & \\
\hline Livløse & 2 & Oplyste & 3 & & & & \\
\hline $\begin{array}{l}\text { Livs- } \\
\text { Oplysningen }\end{array}$ & 1 & & & & & & \\
\hline Livssag & 1 & & & & & & \\
\hline Livs-Stillingen & 1 & & & & & & \\
\hline $\begin{array}{l}\text { Livs- } \\
\text { Udviklingen }\end{array}$ & 1 & & & & & & \\
\hline Livs-Ytring & 1 & & & & & & \\
\hline Menneske-Liv & 1 & & & & & & \\
\hline $\begin{array}{l}\text { Menneske- } \\
\text { Livet }\end{array}$ & 4 & & & & & & \\
\hline Oplives & 1 & & & & & & \\
\hline Oplivelse & 1 & & & & & & \\
\hline
\end{tabular}


Til Nordmoend om en Norsk Høi-Skole (1837, 24 s., 8)

\begin{tabular}{|c|c|c|c|c|c|}
\hline \multicolumn{2}{|c|}{$\begin{array}{l}\text { Det primære begreb } \\
\text { "Frihed" }\end{array}$} & \multicolumn{2}{|l|}{$\begin{array}{l}\text { Det primære begreb } \\
\text { "Folk" }\end{array}$} & \multicolumn{2}{|c|}{$\begin{array}{l}\text { Det primære begreb } \\
\text { "Liv" }\end{array}$} \\
\hline Fri & 7 & Folk & 15 & Folke-Livet & 1 \\
\hline Frie & 1 & Folkefærd & 1 & Folke-Livets & 2 \\
\hline Frihed & 5 & Folkehistorisk & 1 & Liv & 5 \\
\hline Frisindet & 1 & Folkelig & 14 & Livet & 8 \\
\hline Frit & 2 & Folkelige & 11 & Livets & 4 \\
\hline Frivillig & 1 & Folkeliges & 1 & Livlighed & 1 \\
\hline \multirow[t]{21}{*}{ Frivilligt } & 1 & Folkeligt & 3 & Livs-Anskuelse & 1 \\
\hline & & Folkene & 4 & Livs-Stilling & 2 \\
\hline & & Folkenes & 3 & Livs-Stillingen & 1 \\
\hline & & Folket & 10 & Menneske-Liv & 2 \\
\hline & & Folkets & 2 & Menneske-Livet & 1 \\
\hline & & Folks & 1 & Menneske-Livets & 1 \\
\hline & & Folke-Døden & 1 & Natur-Livet & 1 \\
\hline & & Folke-Fiendes & 1 & Aandsliv & 1 \\
\hline & & Folke-Kraft & 1 & & \\
\hline & & Folke-Kræfter & 1 & & \\
\hline & & Folke-Livet & 1 & & \\
\hline & & Folke-Livets & 2 & & \\
\hline & & Folke-Mund & 9 & & \\
\hline & & Folke-Munde & 1 & & \\
\hline & & Folke-Naturen & 1 & & \\
\hline & & Folke-Naturer & 1 & & \\
\hline & & Folke-Stemme & 2 & & \\
\hline & & Folke-Ungdommen & 1 & & \\
\hline & & Folke-Vens & 1 & & \\
\hline & & Folke-Virksomhed & 1 & & \\
\hline & & Ø-Folk & 1 & & \\
\hline
\end{tabular}

